\title{
VI. The Polish Ordinary Courts in Dialogue on International Law
}

Magdalena Matusiak-Frącczak*

\section{Introductory Remarks}

Polish ordinary courts ${ }^{1}$ adjudicate in areas of criminal law and civil law, including labour and social security law. The right to a fair trial requires that the case is verified by at least two court instances ${ }^{2}$ and this rule is preserved both by civil and criminal procedure. ${ }^{3}$ In strictly defined matters a case can be resolved by the Polish Supreme Court, which acts as a court of cassation. It must be noted that Polish law does not classify the Supreme Court as a part of the ordinary courts system. ${ }^{4}$ However, due to the value of its judgments for the ordinary courts we shall consider it as such.

Polish courts issue judgments on the basis of Polish law, which encompasses also public international law. Pursuant to Art. 9 of the Polish Constitution, the Republic of Poland shall respect international law binding upon it. Ratified international agreements are one of the sources of a universally binding law of the Republic of Poland (Art. 87(1) of the Constitution). They constitute part of the domestic

* Dr iur., Assistant Professor, Department of European Constitutional Law, Faculty of Law and Administration, University of Lodz, Poland.

1 In Poland there are at present 321 district courts, 45 provincial courts and 11 appellate courts, Biuletyn Informacji Publicznej, 'Lista sądów powszechnych', <https://bip.ms.gov.pl/ $\mathrm{pl} /$ rejestry-i-ewidencje/lista-sadow-powszechnych/> (access: 21 November 2015).

2 Arts. 45(1) and 175(1) of the Polish Constitution.

3 Art. 367(1) of the Code of Civil Procedure and Art. 425(1) of the Code of Criminal Procedure.

4 Art. 175(1) of the Polish Constitution, Art. 2(1) of the Code of Civil Procedure, Arts. 24-27 of the Code of Criminal Procedure. 
legal order and shall be applied directly after their promulgation in the Journal of Laws of the Republic of Poland (Dziennik Ustaw), unless their application depends on the enactment of a statute (Art. 91(1) of the Constitution). An international agreement ratified upon prior consent granted by a statute shall have precedence over statutes if such an agreement cannot be reconciled with the provisions of these statutes (Art. 91(2) of the Constitution). Since the entry into force of the Polish Constitution international law, at least in theory, is quite broadly applied by Polish courts. The aim of this paper is to show whether when this happens courts use the expertise of international and foreign courts or even enter into the conversation with the judges from other jurisdictions.

A wide understanding of the notion of judicial dialogue has been adopted for the purposes of this study. The notion will denote here any referral made by Polish ordinary courts to decisions of other jurisdictions. In order to answer the posed research question, the following screening method was applied. Courts' rulings are in Poland published in Internet databases. These databases were searched with the use of selected keywords, for example: 'international', 'custom', 'convention', 'tribunal', to find the relevant case law. They were then analysed with the view of identifying instances of dialogue and classified accordingly.

Having collected the research material, it was noticeable that the decisions from other jurisdictions that are the most frequently mentioned by Polish courts are these of the European Court of Human Rights (ECtHR) and the Court of Justice of the European Union (CJEU). Both the European Convention on Human Rights (ECHR) and EU law form a part of the Polish law and they are often directly applicable by the courts. The judgments of these two jurisdictions are widespread, many of them are available in Polish and are broadly commented by Polish scholars. Due to a great quantity of the judgments referring to the decisions of the ECtHR and the CJEU, the scope of the research was limited only to those delivered in years 2010-2015. The referrals to the decisions of the other international bodies, e.g. the United Nations Human Rights Committee (HRC) or the International Court of Justice (ICJ) or courts of other States were occasional. Therefore, they were examined in a more detailed manner and no time limits applied. The study does not deal with the procedural references to the decisions of foreign courts where the application of foreign law ensues from the obligation based, e.g. on the Regulation $593 / 2008^{5}$ or international private law. ${ }^{6}$

5 Regulation (EC) of the European Parliament and the Council on the law applicable to contractual obligations (Rome I) (2008) O.J. L 177/6.

6 As an example of this type of judgments we may present the judgment in Case IV CSK 309/12 (Supreme Court, 8 February 2013), in which the Court referred to the judgments of the German courts on the interpretation of the rules of the Bürgerliches Gesetzbuch on the compensation for traffic accidents, which the Court had to apply on the basis of the Hague Convention on the law applicable to traffic accidents of 4 May 1971. The courts, on the basis of Art. 1143(3) of the Code of Civil Procedure, asked the Ministry of Justice for the explanation of the foreign legal practice. 
As it has been pointed out already in this volume by M. Górski, the judicial dialogue may be classified vis-à-vis the criterion of appropriateness. The dialogue can be proper, fake or decorative and, eventually, failed. ${ }^{7}$ We will explore the examples from all these categories, yet the main focus will be to identify the examples of proper dialogue. By doing so we would like to show the participation of Polish ordinary courts in the development of international law, in the strengthening the rule of law or searching for common judicial standards.

\section{Examples of a Proper Dialogue}

The aim of this part of the paper is to present decisions of Polish courts, in which they enter into proper dialogue with international and foreign bodies. A proper dialogue means courts' rulings "referring to accurately collected case law of other courts and analysing it properly from methodological point of view."

The research revealed four main substantive law categories where such dialogue appears. Polish courts refer to the decisions of international and foreign courts mainly in cases concerning human rights, EU law and customary international law. The fourth group covers every other area of law in which the courts enter into dialogue on international law.

\subsection{Human Rights Protection}

The first area, in which Polish ordinary courts enter into a dialogue with international bodies, is the field of human rights protection. Poland is a party to numerous human rights treaties and these rights form an essential element of the Polish legal system.

The substantial part of the dialogue is made up of references of the courts to the decisions of the ECtHR. This range of cases will be addressed only very briefly, as it is a topic of a more detailed analysis made in this volume by M. Górski. ${ }^{9}$ It seems sufficient to indicate that ordinary courts are acquainted with the judgments of the ECtHR. Many decisions of the Court, especially those rendered

7 See the contribution to this volume: M. Górski, Dialogue between national courts of selected Central and Eastern European States and the ECtHR concerning the ECHR.

8 See: ibidem.

9 See: ibidem. 
against Poland, are translated into Polish and they are published on the websites of the Ministry of Justice ${ }^{10}$ and the Ministry of Foreign Affairs. ${ }^{11}$

The decisions of the ECtHR are mentioned by ordinary courts mostly in the following areas: the right to a fair trial, ${ }^{12}$ the obligation of a State to protect the personal goods of the arrested and the imprisoned persons whilst ensuring appropriate conditions of their imprisonment ${ }^{13}$ the use of the provocation in the criminal procedure, ${ }^{14}$ the freedom of speech, ${ }^{15}$ the compensation for the arbitrary arrest. ${ }^{16}$ In all cases ECtHR judgments are generally invoked to support the courts' own reasoning.

As an example of a proper judicial dialogue we shall discuss a judgment delivered by the Wroclaw District Court in X P 384/13. ${ }^{17}$ The case concerned disciplinary sanction imposed on a school teacher (the plaintiff) who during the staff meeting criticised the behaviour of the school director. The plaintiff opposed to the fact that the director announced the results of the teachers' evaluation by the students in public during the meeting, but instead should have done so in private with every teacher. The plaintiff, in the view of the director, questioned his competences and depreciated his authority. As a result, the director punished the plaintiff giving her a caution. ${ }^{18}$

The plaintiff argued before the court that the penalty violated her freedom of speech, as enshrined in Art. 54 of the Polish Constitution and in Art. 10 ECHR. To solve the case, the Wroclaw District Court referred to numerous judgments of the ECtHR on Art. 10 ECHR, especially in relations between employee and employer, in order to establish a standard of protection of this right, which is common for the European States.

At the beginning it was necessary to establish the attribution of protection under Art. 10 ECHR. The first judgment mentioned by the Wroclaw District

10 Biuletyn Informacji Publicznej, 'Orzecznictwo Europejskiego Trybunału Praw Człowieka', $<$ https://bip.ms.gov.pl/pl/prawa-czlowieka/europejski-trybunal-praw-czlowieka/orzecznictwo-europejskiego-trybunalu-praw-czlowieka/> (access: 2 October 2015).

11 Biuletyn Informacji Publicznej, 'Nowe tłumaczenia wyroków Europejskiego Trybunału Praw Człowieka na język polski', <https://www.msz.gov.pl/pl/polityka_zagraniczna/europejski_ trybunal_praw_czlowieka/aktualnosci/nowe_tlumaczenia_wyrokow_europejskiego_trybunalu_praw_czlowieka_na_jezyk_polski> (access: 2 October 2015).

12 Supreme Court cases: III CZP 16/10 (30 November 2010); III KK 327/12 (5 April 2013); I KZP 14/14 (26 June 2014); I PZ 19/14 (28 October 2014); case II AKz 340/10 (Wroclaw Appellate Court, 17 June 2010).

13 Case III CZP 25/11 (Supreme Court, 18 October 2011); case I ACa 758/12 (Szczecin Appellate Court, 20 December 2012); case I ACa 966/12 (Warsaw Appellate Court, 31 January 2013). Supreme Court cases: III KK 152/10 (30 November 2010); II KK 265/13 (19 March 2014). Case I ACa 662/12 (Łódź Appellate Court, 1 October 2012); case II AKa 91/11 (Lublin Appellate Court, 6 June 2011); case I ACa 201/12 (Warsaw Appellate Court, 20 September 2012).

17 Case X P 384/13 (Wroclaw District Court, 7 June 2013).

18 In Polish: upomnienie. 
Court was a 2009 Wojtas-Kaleta $v$ Poland ${ }^{19}$ where the application was filed by a journalist of the Polish Public Television (TVP S.A.). The applicant as well as many other journalists and artists signed an open protest letter directed to the Board of TVP S.A. criticizing the reduction in the number of cultural programs to the favour of purely commercial ones. The ECtHR found that the reprimand penalty ${ }^{20}$ imposed on the applicant was in conflict with Art. $10 \mathrm{ECHR}$, especially taking into consideration the fact that the applicant's critique was done in good faith and it was not directed against any specific person but only against the employer's policy. In 2013 decision the Wroclaw District Court found the situation in Wojtas-Kaleta $v$ Poland analogous to the one before it. It emphasized that the plaintiff was not acting mala fides against the director or any other teacher, but presented a general opinion that the results should be discussed with everyone in private.

Further the Wroclaw District Court referred to the decision in Sosinowska $v$ Poland, ${ }^{21}$ in which the applicant, a medical doctor, criticized the work of her colleague and his improper treatment of patients. The ECtHR found that the absolute prohibition of critique of one doctor directed at the work of another is contrary to Art. $10 \mathrm{ECHR}$, especially if the critique is induced by the care for patients' health. In the case at stake, the Wroclaw District Court found that the plaintiff's action was only a defence of her colleague, who was criticized in public and, therefore, at risk of ostracism by other teachers.

Another case mentioned by the Wroclaw District Court was Fuentes Bobo $v$ Spain ${ }^{22}$ concerning offensive opinions of the applicant against his employer (public television). As a result of pronouncement of his opinions, the applicant was dismissed, which was found by the ECtHR to be an excessive and disproportionate sanction. Before the incident, the applicant had been for many years an appreciated employee.

Having established, that the case at stake falls under the realm of Art. 10 ECHR, it was indispensable to analyse the principle of proportionality of intervention. The Wroclaw District Court found that not every expression of opinion is protected by Art. 10 ECHR and it may happen that a sanction imposed on an employee is proportionate. As example it pointed out the ruling of the ECtHR in Palomo Sanchez and others $v$ Spain..$^{23}$ The applicants published a magazine, in which they used vulgar language and pictures criticizing their colleagues for giving in court a testimony favourable to their employer. All applicants were dismissed from their work and the ECtHR did not found this sanction excessive. Moreover, the Wroclaw District Court notices, that the ECtHR cited the advisory opinion

\footnotetext{
Wojtas-Kaleta v Poland, App. no. 20436/02 (ECtHR, 16 July 2009).

20 In Polish: nagana.

21 Sosinowska v Poland, App. no. 10247/09 (ECtHR, 18 October 2011).

22 Fuentes Bobo v Spain, App. no. 39293/98 (ECtHR, 29 February 2000).

23 Palomo Sanchez and others v Spain, App. no. 28955/06 (ECtHR, 12 September 2011).
} 
of the Inter-American Court of Human Rights (IACtHR) in OC-5/85 ${ }^{24}$ declaring that freedom of speech is a necessary condition of development of trade unions. It resulted thereof that the freedom of expression is also guaranteed to employees, who thus have the right to criticize their employers, despite subordination that exists in their relations.

On the basis of these opinions the Wroclaw District Court concluded, that the plaintiff's behaviour could not be regarded as exceeding the freedom of expression. Furthermore, referring to Jersild $v$ Denmark ${ }^{25}$ and Nilsen and Johnsen $v$ Norway $^{26}$ the Court emphasized that

freedom of expression constitutes one of the essential foundations of a democratic society and one of the basic conditions for its progress and for each individual's self-fulfillment. Within the limitations of paragraph 2 of Article 10, it is applicable not only to 'information' or 'ideas' that are favorably received or regarded as inoffensive or as a matter of indifference, but also to those that offend, shock or disturb. Such are the demands of that pluralism, tolerance and broadmindedness without which there is no 'democratic society'. As set forth in Article 10, this freedom is subject to exceptions, which must, however, be construed strictly, and the need for any restrictions must be established convincingly. ${ }^{27}$

On that ground the Wroclaw District Court found that there was no reason to impose a penalty on the plaintiff.

The decision of the Wroclaw District Court should be considered as an exemplary proper judicial dialogue. The Court not only cited the opinions of the ECtHR but also showed their relation to the subject matter of the case before the District Court. The Court compared the factual background of the cases before the ECtHR and the outcome of the ECtHR's deliberations with the facts of the case before the District Court and on this basis drew conclusions as to the required level of protection of freedom of speech and the appropriateness of the sanction imposed on the plaintiff by her employer. An additional value of this judgment presents itself in an indirect dialogue of the Wroclaw District Court with the IACtHR, where the ECtHR played a role of an intermediary.

24 Compulsory Membership in an Association Prescribed by Law for the Practice of Journalism, Advisory Opinion OC-5/85, Inter-American Court of Human Rights Series A No. 5 (13 November 1985): "70. Freedom of expression is a cornerstone upon which the very existence of a democratic society rests. It is indispensable for the formation of public opinion. It is also a conditio sine qua non for the development of political parties, trade unions, scientific and cultural societies and, in general, those who wish to influence the public. It represents, in short, the means that enable the community, when exercising its options, to be sufficiently informed. Consequently, it can be said that a society that is not well informed is not a society that is truly free."

Jersild v Denmark, App. no. 15890/89 (ECtHR, 23 September 1994). 
Another international body, whose opinions on human rights had some, albeit limited, influence on decisions of ordinary courts is the Human Rights Committee. The HRC's case-law is mentioned very rarely, it seems that not many judges are familiar with the Committee's activity.

In I CSK 439/13 $3^{28}$ the Supreme Court examined in opinion an opinion of the HRC. The case before the Court concerned a Sikh, Mr. S.P., who was forced by the Border Guards to remove his turban during the customs control. He claimed damages for a breach of his personal interests under the Polish Civil Code ${ }^{29}$ and the freedom of religion.

Firstly, the Supreme Court invoked and analysed several of its own judgments and the case-law of the ECtHR. The Court referred to $X v$ United Kingdom ${ }^{30}$ in which the applicant was also a Sikh who was fined by the British Police due to his riding a motorcycle without a crash helmet, which was required by British law. His application to the ECtHR was rejected by the European Commission for Human Rights as it noticed that the compulsory wearing of crash helmets is a necessary safety measure for motorcyclists. Therefore, the interference with the applicant's freedom of religion was justified by the protection of health. Then the Supreme Court cited the ruling in Phull v France, ${ }^{31}$ in which the factual background was similar to the one in the case at stake. The applicant, who was a practising Sikh, was compelled by the security staff at the airport to remove his turban for inspection as he made his way through the security checkpoint prior to entering the departure lounge. The ECtHR found no violation of the ECHR and emphasized that security checks at the airports are undoubtedly necessary in the interests of public safety, particularly as the measure was only resorted to occasionally.

Moreover, the Court made a comparison of the judgment of the ECtHR in Mann Singh $v$ France $^{32}$ and the opinion of the HRC in Mann Singh $v$ France. ${ }^{33}$ The Supreme Court studied in detail the decisions of these two instances on the prohibition of wearing a turban while taking a photo for a passport and a driving licence, as in the case of the same person the ECtHR and the HRC have issued contrary decisions. The ECtHR has not found any violation of the ECHR, emphasizing that a requirement of removing a turban for the purpose of taking a photo for a driving licence and an identity card is necessary in a democratic society on the grounds of public safety as it reduces the risk of fraud from tampering permits lead, and therefore it falls into the margin of appreciation granted to State. The HRC, on the contrary, found that there was a breach of the applicant's right to freedom of religion. According to the HRC,

\footnotetext{
28 Case I CSK 439/13 (Supreme Court, 17 September 2014).

29 Arts. 23 and 24 of the Civil Code.

30 X v United Kingdom, App. no. 7992/77 (European Commission for Human Rights, 12 July 1978).

31 Phull v France, App. no. 35753/03 (ECtHR, 11 January 2005).

32 Mann Singh v France, App. no. 24479/07 (ECtHR, 27 November 2008).

33 Mann Singh v France, App. no. 1928/2010 (HRC, 19 July 2013).
} 
France has not proven how taking off a turban for purposes of taking a photo would make the identification of the claimant more possible, as in everyday life he wears a turban in a way, which makes his face perfectly visible. The HRC claimed that the sustained character of the violation caused by the State's refusal to issue requested documents was contrary to the principle of proportionality. The Supreme Court emphasized that the situation of the plaintiff in the case at stake, Mr. S.P., was different from the one of Mr. Mann Singh. It concerned the safety of the passengers and the flight and it was a singular and an exceptional interference in Mr. S.P.s freedom of religion, whereas the intrusion in the rights of Mr. Mann Singh was of a permanent and a long lasting character, as he could not obtain important documents for several years due to the lack of a photo. ${ }^{34}$

The analysis of the opinions of the ECtHR and the HRC permitted the Supreme Court to make a conclusion that there was no violation of human rights of Mr. S.P. There was an intrusion with the plaintiff's personal rights and freedom of religion, but it was necessary in a democratic society and neither was it disproportionate, as the obligation to remove the turban was imposed only occasionally.

As it may be noticed, in the area of human rights protection ordinary courts refer to opinions of different international bodies. In that sphere, the most developed dialogue exists with the ECtHR, as the research revealed only one example of a dialogue with the HRC. As we may see from the examples presented above, Polish courts resort to a detailed analysis of decision of other courts to find a common standard of protection of human rights and apply it in cases before them.

\subsection{Customary International Law}

One of the most natural areas of dialogue with international and foreign courts is the area of customary international law. The major subject in this area is State immunity. In the 2010 Natoniewski $i^{35}$ case the Polish Supreme Court was to decide whether the Federal Republic of Germany is protected by State immunity in cases concerning the damages caused during the World War II. The plaintiff, Mr. Natoniewski, claimed damages (a sum of 1000000 PLN) as a compensation for the injuries $^{36}$ suffered during the pacification of Szczecin carried out by the German

34 "W motywach opinii wskazano, że co prawda państwo może powoływać się na ochronę porządku i bezpieczeństwa publicznego, w tym na przeciwdziałanie fałszerstwu dokumentów i tożsamości, jednak skarżone państwo nie wykazało, że dopuszczenie fotografii w turbanie naruszałoby interes ogólny, skoro posiadacz zawsze występuje publicznie ubrany w ten sposób. [...] Wreszcie zastosowanie środka było jedynie okazjonalne (inaczej niż w powołanej wyżej sprawie Mann Singh) i obiektywnie nie przyniosło powodowi uszczerbku, ponieważ badanie zawsze odbywało się w osobnym pomieszczeniu, tylko w obecności funkcjonariusza prowadzącego kontrolę. Zastosowany środek był zatem proporcjonalny."

36 The plaintiff was a 6-year-old child. His head, chest, hands were burned. 
army on 2 February 1944. Mr. Natoniewski claimed that there was no possibility to apply State immunity when the State breached jus cogens norm. There is a noticeable trend in public international law to indicate that in case of conflict between jus cogens norm and State immunity, a peremptory norm is superior and deprives the rule of State immunity of all its legal effects. ${ }^{37}$ Natoniewski gave thus the Supreme Court a possibility to participate in international legal discussion on the relationship between the two norms.

To determine whether Germany could be sued before Polish courts the Court carefully considered many international and national courts decisions. At the beginning the Supreme Court distinguished between two groups of judgments presenting two different views. According to the first approach, the jurisdictional immunity of State has still an absolute character, whereas, according to the second one, certain restrictions may apply. Apart from the referrals to the judgments of the ECtHR ${ }^{38}$ and the CJEU, ${ }^{39}$ the Court examined the judgment of the ICJ of 2002 in Democratic Republic of the Congo $v$ Belgium. ${ }^{40}$ For the Polish Supreme Court the ICJ judgment was an example of a decision adopting the first of the above mentioned views. In this case the ICJ held that even the breach of jus cogens would not enable the abolition of the immunity of the Minister of Foreign Affairs of the Congo while in office. At the time when the ICJ issued its ruling, there was a broad discussion on immunity of State officials in case of serious crimes under international law. The House of Lords in Pinochet ${ }^{41}$ and the French Cour de Cassation in Qaddafi ${ }^{42}$ decided that in this situation, a State official is not protected by immunity. However, the Polish Supreme Court in its decision in $\mathrm{Na}$ toniewski did not make any distinction between immunity of State and that of the Minister of Foreign Affairs. Upon a broad inquiry into the decisions from other jurisdictions, the Court also indicated, that even if there is a tendency in international law to exclude the State immunity in case of a serious breach of human rights law, the ICJ would need to make a pronouncement on the Jurisdictional

37 Al-Adsani v the United Kingdom, App. no. 35763/97 (ECtHR, 21 November 2001), joint dissenting opinion of judges Rozakis and Caflish, joined by judges Wildhaber, Costa, Cabral Barreto and Vajić.

38 Al-Adsani $v$ the United Kingdom, App. no. 35763/97 (ECtHR, 21 November 2001); McElhinney $v$ Ireland, App. no. 31253/96 (ECtHR, 21 November 2001); Kalogeropoulou and others v Greece and Germany, App. no. 59021/00 (ECtHR, 12 December 2002); Waite and Kennedy v Germany, App. no. 26083/94 (ECtHR, 18 February 1999).

39 C-292/05 Erini Lechouritou and others v Dimosio tis Demokratias tis Germanias (CJEU, 15 February 2007); C-172/91 Volker Sonntag v Hans Waidmann, Elisabeth Waidmann and Stefan Waidmann (CJEU, 21 April 1993).

40 Case concerning the arrest warrant of 11 April 2000 (Democratic Republic of the Congo v Belgium) (ICJ, 14 February 2002).

41 Commissioner of Police for the Metropolis and Others, Ex Parte Pinochet (House of Lords, 24 March 1999).

42 Case 00-87215 Qaddafi (French Cour de Cassation, 13 March 2001). 
Immunities of the State (Germany v Italy: Greece Intervening) case $^{43}$ that was at the time pending.

The Supreme Court examined there also numerous decisions of the courts of other States, i.a. of: the United Kingdom ${ }^{44}$ the United States, ${ }^{45}$ Italy ${ }^{46}$ and Greece. ${ }^{47}$ It was part of the Court's research into international custom on jurisdictional immunity of States and definitely it is worth an approval that the Court did not limit the scope of its examination only to international bodies, but it made a detailed scrutiny of various foreign courts' case law. In cases concerning the determination of an existence or a lack of a customary international law, it is indispensable that the courts of different States study opinions of other courts on both, national and international level.

The Supreme Court decided, that the Polish judicial practice acknowledges State jurisdictional immunity as a part of international customary law and is applicable by national courts on the basis of Art. 9 of the Polish Constitution. The immunity has its source in the principle of equality of States (par in parem non habet imperium) and it is an expression of State sovereignty. Its aim is to preserve friendly inter-State relationships. ${ }^{48}$ The Court, referring to its own previous decisions, ${ }^{49}$ indicated that till 1950's State immunity was absolute in every aspect, but nowadays this absolute character is connected only with a sovereign activity of a State (acta iure imperii), whereas a State is not entitled to it when a dispute arises from a commercial transaction entered into by a State or other non-sovereign activity of State (acta iure gestionis).

43 Jurisdictional immunities of the State (Germany $v$ Italy: Greece intervening) (ICJ, 3 February 2012).

44 Jones v Saudi Arabia (House of Lords, 14 June 2006).

45 Liu v Republic of China (United States Court of Appeals, 9 Circuit, 29 December 1989); Republic of Austria v Maria Altmann (United States Supreme Court, 7 June 2004); Guy von Dardel $v$ the USSR (United States DC Circuit Court of Appeals, 15 October 1985).

46 Ferrini v Germany 5044/2004 (Italian Corte di Cassazione, 11 March 2004); Civitella 1072/08 (Italian Corte di Cassazione, 21 October 2008).

47 Perfectory Voiotia v Germany (Distomo) 111/2000 (Greek Special Supreme Court, 4 May 2000); Margellos v Germany 6/2002 (Greek Special Supreme Court, 17 September 2002).

48 The Supreme Court in Natoniewski stated that: "Ostatecznie w polskim orzecznictwie pod wpływem wypowiedzi piśmiennictwa przeważył pogląd uznający na gruncie art. 9 Konstytucji za źródło tego immunitetu powszechnie przyjęty zwyczaj międzynarodowy. [...] U podstaw immunitetu jurysdykcyjnego państw obcych leży zasada równości państw (par in parem non habet imperium). Jest on wyrazem poszanowania suwerenności państw. Zmierza do utrzymania między państwami przyjaznych stosunków."

"Finally, the Polish jurisprudence decided that on the basis of Art. 9 of the Polish Constitution it is the commonly accepted international custom that is the source of this immunity. [...] The basis of the jurisdictional immunity of foreign States is the principle of equality of States (par in parem non habet imperium). It is the expression of the respect to the State sovereignty. It aims at keeping friendly inter-State relationships" (transl. by the author).

49 Supreme Court cases: III PZP 9/90 (26 September 1990); III CSK 293/07 (13 March 2008). 
On the other hand, the Supreme Court noticed on the basis of the detailed information supplied by the Ministry of Justice that whenever States regulated State immunity, State jurisdictional immunity is excluded in cases of injury or damage occurred in the territory of State of the forum. The same rule was adopted in the European Convention on State immunity. ${ }^{50}$ There are also judicial decisions, which accept this rule, ${ }^{51}$ but there exist also such that contradict it. ${ }^{52}$ However, even if a new rule of customary international law has been recently created and it permits claiming damages from a State for injuries it caused and which occurred in the territory of State of the forum, it does not mean, in the view of the Supreme Court, that it can be applied to the events that took place decades ago. ${ }^{53}$

Moreover, jurisdictional State immunity concerns especially the actions that occurred during the time of war or armed conflict and cannot be upheld by such recently created exception. The questions of injuries or damages are then regulated by peace treaties between sovereign States. In relations between individuals and States jurisdictional immunity is granted.

The Supreme Court noticed also that some foreign courts present a view, that jurisdictional State immunity is excluded in case of breach of jus cogens norms, as it means that a State impliedly renounces its immunity. ${ }^{54}$ Yet the Court underlined that in its opinion State may expressly relinquish its immunity, but the renouncement cannot be implied and it does not belong to a national court to interpret international law in a way unaccepted by other States, and the jus cogens exception is not commonly recognized. ${ }^{55}$ Moreover, the jus cogens norms concerned (pro-

50 European Convention on State Immunity (adopted on 16 February 1972, Basel). Art. 11: "A Contracting State cannot claim immunity from the jurisdiction of a court of another Contracting State in proceedings which relate to redress for injury to the person or damage to tangible property, if the facts which occasioned the injury or damage occurred in the territory of the State of the forum, and if the author of the injury or damage was present in that territory at the time when those facts occurred."

51 Liu v Republic of China (United States Court of Appeals, 9 Circuit, 29 December 1989); Perfectory Voiotia v Germany (Distomo) 111/2000 (Greek Special Supreme Court, 4 May 2000); Ferrini v Germany 5044/2004 (Italian Corte di Cassazione, 11 March 2004); Hugo Princz v Federal Republic of Germany (United States DC Circuit Court of Appeals, 14 April 2003); Hirsch v State of Israel and State of Germany (United States District Court (New York), 8 April 1997); Bruce Smith v Socialist People's Libyan Arab Jamahiriya (United States Court of Appeals, 2 Circuit, 26 November 1996).

52 Margellos v Germany 6/2002 (Greek Special Supreme Court, 17 September 2002); Jones v Saudi Arabia (House of Lords, 14 June 2006).

53 Republic of Austria v Maria Altmann (United States Supreme Court, 7 June 2004).

54 Liu v Republic of China (United States Court of Appeals, 9 Circuit, 29 December 1989); Guy von Dardel v the USSR (DC Circuit Court of Appeals, 15 October 1985); Perfectory Voiotia v Germany (Distomo) 111/2000 (Greek Special Supreme Court, 4 May 2000); Ferrini v Germany 5044/2004 (Italian Corte di Cassazione, 11 March 2004); Civitella 1072/08 (Italian Corte di Cassazione, 21 October 2008).

55 Hugo Princz v Federal Republic of Germany (DC Circuit Court of Appeals, 14 April 2003); Hirsch v State of Israel and State of Germany (United States District Court (New York), 8 April 1997); Bruce Smith v Socialist People's Libyan Arab Jamahiriya 95-7930, 95-7931, 95-7942 (United 
hibition of torture, prohibition of genocide) have substantive character, whereas jurisdictional State immunity is of procedural nature so they cannot reciprocally influence one another.

It is worth underlining that the Supreme Court's judgment in Natoniewski was noticed and had an impact on international level, as it was referred to by the International Court of Justice in its decision in Jurisdictional Immunities of the State (Germany v Italy: Greece Intervening) ${ }^{56}$ and by the European Court of Human Rights in Jones and Others $v$ the United Kingdom. ${ }^{57}$ The ICJ's ruling concerned the responsibility of Germany for damages caused during World War II, so the circumstances were exactly the same as in Natoniewski. First, agreeing with the Polish Supreme Court, the ICJ noticed, that the Basel Convention ${ }^{58}$ does not cover the immunity of a State for the acts of its armed forces. Then the ICJ described in detail the reasons, why the Polish Court decided that Germany had jurisdictional immunity in cases on the acts committed during World War II and mentioned, that the Polish Supreme Court was one of the bodies presenting opinion that State immunity does not depend on the gravity of the act of which it is accused or the peremptory nature of the rule which it is alleged to have violated.

The judgment of the ECtHR concerned the right to a fair trial (Art. 6 ECHR). The applicants claimed they had been tortured in the Kingdom of Saudi Arabia by its officials and brought civil claims before the courts of the United Kingdom. The claims were dismissed, as the courts decided in favour of State immunity, which was granted to the Kingdom of Saudi Arabia and its officials even in the case of an alleged breach of the jus cogens norm, namely the prohibition of torture. The ECtHR was provided by the applicants and the United Kingdom with a comparative material on the practice of 21 Members of the Council of Europe and many other States worldwide in the area of State immunity. The information presented contained also the decision in Natoniewski. For the European Court of Human Rights the decisive factor was however the judgment of the International Court of Justice in Jurisdictional Immunities of the State (Germany v Italy: Greece Intervening).

The above-mentioned cases prove, that where important issues of international law are concerned the dialogue between different courts is multilateral and one can observe an interaction, what has positive influence on development of international customary law.

States 2 Circuit Court of Appeals, 26 November 1996); Jones v Saudi Arabia (House of Lords, 14 June 2006); Al-Adsani $v$ the United Kingdom, App. no. 35763/97 (ECtHR, 21 November 2001); McElhinney $v$ Ireland, App. no. 31253/96 (ECtHR, 21 November 2001); Kalogeropoulou and others v Greece and Germany, App. no. 59021/00 (ECtHR, 12 December 2002); Waite and Kennedy v Germany, App. no. 26083/94 (ECtHR, 18 February1999).

56 Jurisdictional Immunities of the State (Germany v Italy: Greece Intervening) (n. 44).

57 Jones and Others $v$ the United Kingdom, App. nos 34356/06 and 40528/06 (ECtHR, 14 January 2014).

58 European Convention on State immunity (adopted on 16 May 1972 in Basel). 
The other example of Polish cases on State immunity which had a considerable impact internationally concerns immunity from enforcement. The former employee of the Nigerian Embassy in Poland wanted to institute the enforcement proceedings against her employer and required reinstitution and imposition of fine. ${ }^{59}$ Basing on the ICJ's judgment in Jurisdictional Immunities of the State (Germany $v$ Italy: Greece Intervening), the Provincial Court emphasized that State immunity in the enforcement proceedings is wider than the jurisdictional immunity. A mere fact that there has been a final judgment delivered by a national court against a State does not mean that the enforcement proceedings can be instituted against that State on such basis. The international custom on immunity from jurisdiction and the immunity from enforcement differs as each of them has its' separate prerequisites. For the enforcement proceedings against other State's property it has to be ascertained that the property is used for the purposes other than non-commercial government actions or the State has expressly agreed to the application of the enforcement proceedings to a given property, or the State has indicated a property that can be the object of the enforcement proceedings. ${ }^{60}$

The Warsaw Provincial Court referred as well to the judgments of the courts of other States. One of them was the 1977 landmark decision of the German

59 Case XXI Pz 95/14 (Warsaw Provincial Court, 26 June 2014).

60 "W tym miejscu na szczególną uwagę zasługuje wyrok Międzynarodowego Trybunału Sprawiedliwości z dnia 3 lutego 2012 r. w sprawie Germany v. Italy: Greece Intervening - jurisdictional immunities of the State, w którym Trybunał wskazał, że immunitet chroniący przed środkami przymusu własność państwa znajdującą się na terytorium obcego państwa jest szerszy niż immunitet jurysdykcyjny. Z faktu wydania wyroku przeciwko obcemu państwu nie wynika ipso facto, że państwo to może być podmiotem środków przymusu na terytorium państwa forum w celu wykonania wydanego wyroku - normy zwyczajowego prawa międzynarodowego odnoszące się do immunitetu egzekucyjnego i immunitetu jurysdykcyjnego są więc różne i muszą być oddzielnie stosowane. Trybunał sformułował także warunki, które muszą być spełnione, aby środek przymusu mógł być zastosowany przeciwko mieniu należącemu do państwa obcego: mienie to musi być wykorzystywane do działań niesłużących celom rządowym o charakterze niekomercyjnym lub państwo to wyraźnie zgodziło się na zastosowanie środka przymusu lub wskazało mienie, o które chodzi dla celów zaspokojenia roszczenia prawnego."

"Here a special attention should be given to the judgment of the International Court of Justice of 3 February 2012 in case Germany v Italy: Greece Intervening - jurisdictional immunities of State, in which the Court indicated that the immunity protecting from coercive measures a State property placed on a territory of other State is broader than jurisdictional immunity. It does not result ipso facto from a mere fact of giving a judgment against foreign State, that a State can be an object of coercive measures on a territory of a foreign State in the aim of the execution of a given ruling - the rules of international customary law on immunity from enforcement proceedings and jurisdictional immunity are thus different and they should be applied separately. The Court has also elaborated conditions, which should be fulfilled, if the coercive measure against the property of other State is to be applied: the property should not be used for governmental purposes of non-commercial character or the State has expressly agreed for the application of coercive measure or has designated property that can be used for the satisfaction of a legal claim" (transl. by the author). 
Constitutional Court in Philippine Embassy, ${ }^{61}$ in which the German Court stated inter alia that the receivables from a current ordinary bank account of an embassy of a foreign State existing in the forum State and intended to cover the embassy's expenses and costs are not subject to execution by the forum State. ${ }^{62}$ The Warsaw Court invoked also the judgments, in which the courts of other States decided that the bank accounts used by a foreign State only for the commercial transactions purposes do not have the privilege of immunity from enforcement proceedings. ${ }^{63}$

On the basis of these judgments the Warsaw Provincial Court ordered the District Court for the capital city of Warsaw to ascertain, whether the enforcement proceedings on the reinstitution could be instituted against the $\mathrm{Ni}$ gerian Embassy. A separate analysis should concern the possibility of the imposition of a fine, especially taking into account that it may encroach upon the principle of equal sovereignty of States. As the reinstitution belongs to labor law, and thus forms a part of acta de iure gestionis, the fine is a repressive measure, so the defendant in the case at stake might remain protected by the immunity from enforcement.

Deciding on the existence of a norm of customary international law and its scope requires referring to decisions of international and foreign courts. The above mentioned examples of proper judicial dialogue, although scarce, show that ordinary courts can carry on a detailed scrutiny of opinions of other bodies and on that basis draw their own conclusions that are noticed on the international level, as the example of Natoniewski shows.

\subsection{Application of EU Law}

The dialogue on EU law between ordinary courts and the CJEU occurs much more often and it is of a different scope and character, due to the role that EU law plays in the national law of the EU Member State. The dialogue between Polish ordinary courts and the CJEU occurs usually through the procedure of preliminary rulings, what is described in this volume by A. Czaplińska. ${ }^{64}$

Nevertheless, for the purposes of this contribution it is worth to mention other examples of the references to EU law. The Warsaw Appellate Court in I ACa

61 Case 2 BvM 1/76 (German Constitutional Court, 13 December 1977).

62 "Forderungen aus einem laufenden, allgemeinen Bankkonto der Botschaft eines fremden Staates, das im Gerichtsstaat besteht und zur Deckung der Ausgaben und Kosten der Botschaft bestimmt ist, unterliegen nicht der Zwangsvollstreckung durch den Gerichtsstaat." Alcom Ltd. v Republic of Colombia (House of Lords, 12 April 1984). Here the House of Lords reaffirmed what the German Constitutional Court said that a bank account used by the State or an embassy to cover the day-to-day expenses of an embassy, clearly serves sovereign purposes and therefore is immune from enforcement measures. See also: Islamic Republic of Iran v Société Eurodif and others 82-12462 (French Cour de Cassation, 14 March 1984).

64 See in this volume: A. Czaplińska, 'The Preliminary Reference Procedure as an Instrument of Judicial Dialogue in the EU - the CEE Perspective'. 
$1663 / 13^{65}$ not only referred to the judgments of the CJEU, but made a critical examination of Luxembourg Court's jurisprudence and entered into a reasoned discussion with the CJEU. The Appellate Court decided not to apply to the CJEU under the procedure of preliminary ruling.

The dispute in the case at stake concerned copyrights and the unlawful use of the plaintiff's song in election spot of one of candidates to the Polish Parliament, which was accessible through clickable Internet link.

The Warsaw Appellate Court differed with the CJEU's opinion expressed in C-466/12 Svensson, ${ }^{66}$ in which the Court of Justice held that the provision on a website of clickable links to works freely available on another website does not constitute an "act of communication to the public", because there can be no "new public' as every person having access to the Internet may view any websites available therein. The Warsaw Appellate Court, pointing to the judgment in C-306/05 $S G A E{ }^{67}$ concerning works communicated by means of television sets installed in hotel rooms, decided that the CJEU in C-466/12 Svenson has erroneously departed from its previous jurisprudence. According to the Appellate Court, the websites are addressed to different public in different States, they are published in different languages and it cannot be said a priori that a clickable link to a website does not break copyrights, because a given work has already been published on another website, so anyone could access it freely. The Warsaw Appellate Court also emphasized that the determination of an "act of communication to the public" should always be based on a detailed analysis of a case also when it concerns clickable Internet links. ${ }^{68}$

Moreover, the Appellate Court showed an interesting approach to foreign jurisdictions. The Court rejected the arguments of the defendant based in the rulings of the courts of the United States of America, ${ }^{69}$ stressing that the continental copyright system, so the one in Poland and in the EU, is very different from the American one. On this ground, the Court held that the US-courts' decisions could not be taken into consideration when applying the relevant Polish and the EU laws. They

65 Case I ACa 1663/13 (Warsaw Appellate Court, 7 May 2014).

66 C-466/12 Nils Svensson, Sten Sjögren, Madelaine Sahlman, Pia Gadd v Retriever Sverige AB (CJEU, 13 February 2014).

67 C-306/05 Sociedad General de Autores y Editores de España (SGAE) v Rafael Hoteles SA (CJEU, 7 February 2006).

68 "Rozumowanie Trybunału prowadzi bowiem do wniosku, że w przypadku wydania książki przez wydawcę inny wydawca, drukując i wydając za pośrednictwem tych samych kanatów dystrybucji taką samą książkę na takich samych warunkach, nie narusza monopolu autorskiego. Wniosek taki logicznie wypływa z rozumowania Trybunału, jednak nie może być on zaakceptowany jako prawidłowy zarówno na gruncie ustawy polskiej, jak i ustawodawstwa Unii Europejskiej. W konsekwencji, w opinii Sądu Apelacyjnego nie można się w tej części zgodzić z rozumowaniem Trybunału, a co za tym idzie - nie można przyjąć, iż w każdym wypadku umieszczanie odwołań (linków) nie narusza monopolu autorskiego."

69 It is not indicated by the Warsaw Appellate Court which American judgments have been mentioned by the defendant. 
could only be used as an evidence on the evolution of the copyright law in one of the most technically developed States in the world. ${ }^{70}$

Another example are the decisions of the Polish Supreme Court, [in:] II CSK $406 / 10,{ }^{71}$ II CSK $541 / 10^{72}$ and II CSK $326 / 10,{ }^{73}$ all adopted on the 16 February 2011 by the same judges. The cases concerned the determination of the court's jurisdiction in insolvency proceedings, when a debtor runs business in two or more different States and the interpretation of Art. 3(1) and (2) of the Council Regulation (EC) No. 1346/2000. ${ }^{74}$ The plaintiffs requested the opening of the insolvency proceedings in Poland, whereas there was already an insolvency proceeding in progress against the same entrepreneur, instituted in France. In its reasoning the Supreme Court referred to the two orders of the High Court of Justice in London delivered in Enron Directo $S A,{ }^{75}$ in which the High Court of Justice developed the theory of mind of management and rebutted the presumption based on the registered office. The theory applied by the High Court in London was examined in detail and confronted by the Polish Supreme Court with the business activity theory, advanced by the CJEU in C-341/04 Eurofood..$^{76}$ The aim of the Supreme Court was to discuss two different approaches to the question at hand and to choose the most proper one.

Ultimately, the Supreme Court decided in favor of the business activity theory, established by the Court of Justice. The Supreme Court concluded, that the understanding of the Council Regulation by virtue of the theory of mind of management would be too subjective and it would lessen the protection of the rights of creditors. Debtors could manipulate the prerequisites of establishing court's jurisdiction by moving its seat to a State in which insolvency law is more favorable to them. At the end, the theory of mind of management could too easily lead to forum shopping. That is why, basing its view on teleological interpretation of the Regulation, the Supreme Court chose an approach that to a higher degree permits creditors for a real verification of circumstances justifying jurisdiction.

70 "Chybione są argumenty oparte na orzeczeniach sądów Stanów Zjednoczonych Ameryki Północnej. Zasadniczo różny jest system prawa autorskiego kontynentalny - którego częścią jest tak Polska, jak i Unia Europejska - oraz system amerykański. Wskazane orzeczenia opierają się na instytucji fair use, która nie może być porównywana do instytucji dozwolonego użytku. Nie mogą one dlatego stanowić podstawy do rozważań w zakresie stosowania prawa w niniejszym postępowaniu, mogą jedynie dawać wskazówkę co do zmian w rozumieniu prawa zachodzącym na terenie jednego z najbardziej zaawansowanych technologicznie państw." Case II CSK 406/10 (Supreme Court, 16 February 2011).

Case II CSK 541/10 (Supreme Court, 16 February 2011).

Case II CSK 326/10 (Supreme Court, 16 February 2011).

Council Regulation (EC) No. 1346/2000 of 29 May 2000 on insolvency proceedings (2000]) O.J. L 160. 
The application of EU law may require not only references to the CJEU case law, but sometimes also to the decisions of the EU Member States' courts. On one hand there are rulings in which Polish courts enter into a discussion with CJEU and foreign courts, by making detailed analysis and presenting their own conclusions. On the other, there are also examples of the decisions of ordinary courts in which courts simply enumerate appropriate CJEU's rulings to support their opinions, without much critical deliberation. ${ }^{77}$

\subsection{Other Areas of Judicial Dialogue}

Other instances, where ordinary courts deal with international law and discuss international or foreign courts' decisions escape any categorization. These cases are lumped in this final part, as they do have one common feature, namely their sole purpose is to strengthen the courts' own reasoning.

The first case discussed concerns the application of the Convention on the Contract for the International Carriage of Goods by Road (CMR Convention). ${ }^{78}$ In its judgment in I ACa $111 / 13^{79}$ the Szczecin Appellate Court referred to the decisions of the French Cour de Cassation ${ }^{80}$ and of the Belgian Koophandel te Antwerpen ${ }^{81}$ in which the Courts underlined that to determine the carrier's liability, the entirety of circumstances has to be taken into account, also whether the robbery had been committed by a third person. The Szczecin Appellate Court pointed out that the verification, whether the carrier followed all obligations and standards binding upon them requires taking into consideration particular circumstances of a given case. A robbery might, but as well might not, be a reason for a release of the carrier from his liability.

The Warsaw Appellate Court in I ACa 696/0382 and the Szczecin Provincial Court in VIII Ga $31 / 13^{83}$ both cited the rulings of the Belgian Hof van Beroep te Antwerpen ${ }^{84}$ and Tribunal de Commerce de Liège ${ }^{85}$ and additionally the Warsaw Appellate Court referred to the decision of the French Cour de Cassation. ${ }^{86}$ These

77 The examples of decision of the Supreme Court's which contain decorative dialogue are the following: II PK 207/12 (27 February 2013), IV CSK 202/13 (28 February 2014), III CZP 113/13 (7 February 2014).

78 Convention on the Contract for the International Carriage of Goods by Road (CMR Convention) (19 May 1956).

79 Case I ACa 111/13 (Szczecin Appellate Court, 9 May 2013).

80 The Court referred to the particular case as: (French Cour de Cassation, 14 May 1992).

81 The Court referred to the particular case as: (Belgian Koophandel te Antwerpen, 3 March 1976). Case I ACa 696/03 (Warsaw Appellate Court, 4 February 2003).

Case VIII Ga 31/13 (Szczecin Provincial Court, 8 March 2013).

The Court referred to the particular case as: (Belgian Hof van Beroep te Antwerpen, 8 November 1989).

85 The Court referred to the particular case as: (Belgian Tribunal de Commerce de Liège, 27 June 1985).

86 The Court referred to the particular case as: (French Cour de Cassation, 18 April 1989). 
judgments were mentioned to strengthen the Courts' thesis that an entrepreneur acts as a forwarding agent only if this is stipulated expressly in the contract. In all other instances an entrepreneur is considered to be a carrier.

In all the above-mentioned cases ordinary courts used foreign decisions to support their own reasoning and to demonstrate that their interpretation of various provisions of the CMR Convention is in line with the opinions of other courts.

Ordinary courts use this technique especially if they deal with a groundbreaking interpretation or with new legal problems, e.g. in the field of financial instruments. The example is the decision of the Bialystok Appellate Court ${ }^{87}$ that concerned the contract of the currency option. The Appellate Court started its reasoning by comparing Polish and German regulations of the currency option contracts. It found many similarities and decided to analyze in detail the German case law, especially in the area of the bank's informative obligations towards its clients. The Appellate Court found German case-law relevant to interpret Polish regulations. ${ }^{88}$

87 Case I ACa 833/12 (Bialystok Appellate Court, 21 January 2013). The Court referred to Case XI ZR 33/10 (German Bundesgerichtshof, 22 March 2011).

88 "Dodać tylko należy, że z wyroku niemieckiego Trybunału Federalnego z dnia 22 marca 2011 roku (XI ZR 33/10), który dotyczy zakresu obowiązków informacyjnych i lojalnościowych banku wobec klienta w związku z zawieraniem transakcji pochodnych, wynika, że bank powinien odpytać klienta na okoliczność ryzyka inwestycyjnego, które jest w stanie podjąć - niezależnie od wykształcenia ekonomicznego klienta, wyjaśnić ryzyko 'produktu', tak by klient w zakresie tego 'produktu' miał zasadniczo ten sam poziom wiedzy co bank, uświadomić klientowi negatywną dla klienta, inicjalną wycenę produktu, gdyż taka wycena sama w sobie wskazuje na poważny konflikt interesów banku i klienta, uświadomić klientowi konflikt interesów, jeżeli struktura ryzyka 'produktu' jest przez bank celowo przesunięta na niekorzyść klienta. Trybunat Federalny nie wiązał przy tym obowiązków informacyjnych banku ze statusem konsumenckim klienta. Prowadzenie działalności gospodarczej przez klienta nie ma wpływu na obowiązki informacyjne banku. Istotny dla obowiązków informacyjnych banku jest jedynie brak wystarczającej wiedzy klienta dla oceny ryzyk z transakcji na poziomie zasadniczo zbliżonym, w zakresie zawieranej transakcji, do wiedzy banku. Kwalifikacje zawodowe klienta nie mają zasadniczo znaczenia. Trybunał Federalny zwrócił uwagę, że doświadczenie zawodowe klienta musiałoby właściwie dotyczyć przygotowywania i zawierania transakcji pochodnych, tak by klient niejako 'od kuchni' posiadł wiedzę na temat skutków konkretnej, zawieranej transakcji porównywalną z wiedzą banku. Ogólna wiedza na temat transakcji nie byłaby więc wystarczająca. Przyjęcie, że klient był zorientowany w ryzykach wywoływanych przez transakcję tylko na tej podstawie, iż zawierał transakcje w innym banku, jest nieuprawnione. Doświadczenie klienta uzasadniające odstąpienie od wyczerpującego poinformowania o właściwościach i możliwych skutkach transakcji musiałoby dotyczyć takich samych transakcji, przy czym nie chodzi tylko o typ transakcji, czy ich podtyp. Spostrzeżenia Trybunału Federalnego znajdują zastosowanie do realiów polskich, albowiem Trybunat ten rozstrzygał właściwie na podstawie ogólnych zasad odpowiedzialności odszkodowawczej ex contractu ( $\$ 280$ niemieckiego kodeksu cywilnego), a po części również na podstawie przepisów niemieckiej ustawy o obrocie papierami wartościowymi (§ 31.1.2 niemieckiej ustawy o obrocie papierami wartościowymi), odpowiadających regulacjom art. 471 k.c. i $\S 6$ ust. 1 rozporządzenia Ministra Finansów z dnia 28 grudnia 


\section{Examples of a Decorative Dialogue}

We have to recall that fake or decorative dialogue means the one "pretending to refer to the case-law of other courts but in fact just decorating the reasoning by random references to inappropriately collected and inaptly analysed decisions." ${ }^{89}$ While Polish courts engage infrequently in the proper judicial dialogue with other jurisdictions, the decorative references seem to be more common.

As an example of a decorative dialogue of Polish ordinary courts we can point to the reference to the Human Rights Committee in a decision which concerned family law and the State's obligation to respect one's private and family life, as enshrined i.a. in Art. 17 of the International Covenant on Civil and Political Rights

2005 roku w sprawie trybu i warunków postępowania firm inwestycyjnych oraz banków powierniczych (Dz. U. z 2006 roku Nr 2, poz. 8)."

"It must be added that it results from the judgment of the German Federal Tribunal of 22 March 2011 (XI ZR 33/10), which concerns the scope of information and loyalty obligations of bank towards its clients in connection with contracts of derivate transactions, that a bank should question its client on the investment risk that the client is able to undertake - regardless of client's economic education. The bank should also explain the risk of a 'product', so that the client has the same level of knowledge of a 'product' as a bank itself, it should inform the client about a negative (from their stance), initial pricing of a product, as this pricing itself shows a serious conflict of interests of bank and its client, inform client about the conflict of interests, if the structure of the 'product's' risk is wilfully shifted by bank to the disadvantage of its client. The Federal Tribunal did not connect the information obligations of a bank with a consumer status of its client. Running a business activity by a client has no influence on bank's information obligations. The crucial aspect for bank information obligations is the lack of sufficient client's knowledge on the evaluation of risks of transaction to the level fundamentally close to bank's knowledge, as far as it concerns given transaction. Client's professional skills are principally of no importance. The Federal Tribunal noticed, that client's professional experience should be actually connected to preparation and conclusion of derivate transactions, so that the client had practical knowledge on the effects of a given transaction, comparable to the bank's knowledge. A general knowledge on transaction is not enough. Assuming that the client was knowledgeable of risks caused by transaction only on this ground, that client had contracts with other bank, lacks justification. A client's experience, justifying resignation from exhausting information about properties and possible effects of transaction should concern exactly the same transactions, but it does not mean only the type or subtype of it. The remarks of the Federal Tribunal are applicable in Polish reality, as the Tribunal solved the case actually on the basis of general rules of liability for damages ex contractu ( $\S 280$ of the German Civil Code), and partially on the basis of the German statute on securities trading ( $\S 31.1 .2$ of the German statute on securities trading), which correspond to Art. 471 of the Polish Civil Code and $\S 6(1)$ of the regulation of the Ministry of Finance of 28 December 2005 on the terms and procedures for investment firms and trust banks (O.J. 2006.2.8)."

M. Górski, op. cit. (n. 8). 
(ICCPR). ${ }^{90}$ In its ruling in case II CKN $321 / 99^{91}$ the Supreme Court made only a general remark, that according to the HRC the prohibition of unlawful interference in one's private life means that no intrusion is permissible, except for the situations strictly regulated by law. Nevertheless, the national legislation that regulates the interference of the State's organs in the sphere covered by Art. 17 ICCPR must comply with the objectives and terms of the Covenant. The Supreme Court did not indicate any specific decision of the Human Rights Committee. The sole aim of this general reference was to add value to its own reasoning. The Court additionally mentioned (briefly and generally) Art. 8 ECHR (the right to respect for private and family life) and the Polish Constitution (Art. $31^{92}$ and Art. $47^{93}$ ) without indicating any decisions of the ECtHR or of the Polish Constitutional Tribunal.

For example, at one instance the Polish Supreme Court referred to the judgment of the International Court of Justice. In case V CSK 295/07, ${ }^{94}$ the Court dealt with the effects of the nationalization acts of Polish authorities of 2005 and the indemnization agreement between Poland and the United States of America. ${ }^{95}$ Following the agreement concluded to solve the problems of the property left by American citizens after the II World War on the territory of Poland, the United States accepted the sum of 40000000 USD in full settlement and discharge of all claims of nationals of the United States against the Government of Poland because of the nationalization and other forms of taking over property by Poland. The American citizens were supposed to address their claims before the US Government. If they accepted the damages, they had to renounce their property rights. Recently some of them questioned the amount of remuneration obtained or claimed damages if they had not used the procedure offered by the US authorities. The case at stake was one of many similar before Polish courts. The Supreme Court referred to its previous case-law and the judgments of the Polish Constitutional Court on just compensation in nationalization cases, and interestingly, also to the ICJ Barcelona Traction ${ }^{96}$ decision. The Supreme Court highlighted that although the civilised nations are obliged to protect private property, the property right is not of an absolute character, it can be restricted by law, or even declined to an individual provided that a condition of just compensation is fulfilled. Regarding damages, the Court noted that there

90 The International Covenant on Civil and Political Rights (adopted 16 December 1966, entered into force 23 March 1976) 999 UNTS 171 (ICCPR).

Case II CKN 321/99 (Supreme Court, 18 August 1999).

The principle of proportionality.

The right to respect for private and family life.

Case V CSK 295/07 (Supreme Court, 12 December 2007).

Agreement on settlement of claims of United States Nationals between the United States of America and Poland (16 July 1960).

Barcelona Traction, Light and Power Company (Belgium v Spain) (ICJ, 24 July 1964). 
is no common international practice ${ }^{97}$ and only in this respect the Court cited Barcelona Traction, unfortunately without mentioning any specific paragraphs of the judgment. In its decision the ICJ did not examine the merits of the case, the property rights claims nor made any statements concerning the acceptable level of protection of this right. The dispute before the ICJ was between Belgium and Spain and it concerned the Spanish acts of nationalization, inter alia of the property of the Barcelona Traction, Light and Power Company, Limited, whose property rights were infringed. The main issue before the ICJ was to determine which State may exercise the diplomatic protection. It appeared that it was not Belgium, that brought the case to the ICJ but Canada. ${ }^{98}$ The case was therefore dismissed.

\section{Examples of a Failed Dialogue}

Failed dialogue denotes such instance of a dialogue that misses "the opportunity to refer to the case law of other courts at all where one should reasonably expect that such jurisprudence is presented." 99 There are way too many of examples

97 "Na marginesie powyższych rozważań, należy jeszcze zwrócić uwagę, że ocena prawna aktów nacjonalizacji czy też wywłaszczenia jest wyjątkowo złożona i nie może ograniczyć się tylko do przepisów u.d.w. Należy oddzielić od siebie sam problem wpisu prawa własności Skarbu Państwa jako rezultatu nacjonalizacji mienia osób prywatnych od jego przesłanek w prawie wewnętrznym z jednej strony oraz aspektów prawnomiędzynarodowych odpowiedzialności odszkodowawczej państwa za akt nacjonalizacji z drugiej strony. Prawo własności nie jest prawem absolutnym, choć do ogólnych zasad prawa narodów cywilizowanych należy jego ochrona; nie ma także powszechnej praktyki międzynarodowej, gdy chodzi o zasady indemnizacji z tytułu wywłaszczeń (por. m.in. wyrok Międzynarodowego Trybunału Sprawiedliwości w sprawie Belgia przeciwko Hiszpanii - Barcelona Traction, Light and Power Company, Zbiór Orzeczeń MTS 1970, s. 3 i n.). Jak podkreśla się zarówno w orzecznictwie Sądu Najwyższego (por. wyrok z dnia 23 września 2004 r., III CK 401/03, OSNC 2005 nr 7-8, poz. 148), jak i Trybunału Konstytucyjnego (postanowienie z dnia 24 października 2000 r., SK 31/99, OTK-ZU 2000 nr 7, poz. 262), przejęcie przez Skarb Państwa mienia obywateli innych państw następowało na podstawie szeregu aktów normatywnych, do których należy m.in. dekret z dnia 8 marca 1946 r. o majątkach opuszczonych i poniemieckich (Dz. U. Nr 13, poz. 87 z późn. zm.) czy też tzw. dekrety nacjonalizacyjne. W ocenie Sądu Najwyższego w składzie rozpoznającym niniejszą sprawę, Układ rządowy pomiędzy USA a PRL dotyczył nie tyle nabycia własności jako takiego, ile raczej zasad wypłaty odszkodowań za mienie przejęte zgodnie z prawem obowiązującym ówcześnie w Polsce."

98 The seat of the company was located in Toronto, Canada, but it was connected to Belgium due to the fact that the company's shareholders were Belgian nationals. 
across the research conducted in this project. This section offers a short selection of such instances where courts' 'hands-off' approach may be considered as highly problematic.

\subsection{Human Rights}

There are many judgments concerning human rights, that are based solely on references to the decisions of Polish courts and tribunals, without any reference to the rulings of international bodies. The Wroclaw Appellate Court's decision ${ }^{100}$ on lustration proceedings may serve as an example. The Court carefully analysed the decisions of the Supreme Court and of the Constitutional Tribunal. It examined the nature of lustration proceedings to determine whether it is of a criminal character. Although this issue was decided by the European Court of Human Rights in Moczulski v Poland, ${ }^{101}$ the Appellate Court hardly observed that both the Constitutional Tribunal and the ECtHR consider this procedure to be a criminal one. ${ }^{102}$

\subsection{International Customary Law}

Even though, as it seems, the judgments concerning State immunity permit Polish ordinary courts for a detailed analysis of the decisions of foreign jurisdictions, the opportunity is not always seized. Case III CSK 293/0 $7^{103}$ was brought to the Supreme Court by a Polish company against Turkey. The former claimed compensation for a violation of its property right by unlawful seizure of company's property on a basis of the regulation of the Turkish Ministry of Energy. The Court was aware that it had to apply customary international law and even underlined that it is authorized to do that under the Polish Constitution (i.a. Art. 9 which states that the Republic of Poland shall respect international law binding upon it). However, the Courts' inquiry into international customary law on State immunity is highly disappointing. Since customary law is based on usus and opinio iuris, the court had to analyse also the case law of domestic and international courts. ${ }^{104}$ Instead of invoking domestic or international courts' decisions, the Supreme Court mentioned

100 Case II AKz 542/10 (Wroclaw Appellate Court, 26 October 2010).

101 Moczulski v Poland, App. no. 49974/08 (ECtHR, 19 November 2011).

102 "Zarówno Trybunat Konstytucyjny, jak też Europejski Trybunał Praw Człowieka (o czym w sposób zdecydowany i jednoznaczny pisze Trybunał Konstytucyjny między innymi w wyroku z dnia 11 maja 2007 r., sygn. akt K 2/07; zob. także wyrok Trybunału Konstytucyjnego z dnia 4 lipca 2002 r., P 12/01, OTKA 2002, nr 4, poz. 50) wielokrotnie stwierdzały, że postępowanie lustracyjne ma charakter penalny. Świadczy o tym zarówno charakter czynu, za który sprawca ponosi odpowiedzialność, charakter i dolegliwość sankcji za ten czyn przewidzianych, jak też reguły postępowania, w toku którego stwierdzane jest ewentualne popełnienie czynu zarzucanego i orzekane są sankcje będące jego prawną konsekwencją."

103 Case III CSK 293/07 (Supreme Court, 13 March 2008).

104 C. Mik, 'Jus cogens in contemporary international law' (2013) Polish Yearbook of International Law XXXIII 50. 
its own rulings ${ }^{105}$ underlining that the principle of State sovereignty does not allow Polish courts to adjudicate cases against other States acting within their sovereign powers (acta iure imperii), however the immunity does not cover non-sovereign acts (acta iure gestionis). The Court referred as well to the 1961 Vienna Convention on Diplomatic Relations ${ }^{106}$ and the European Convention on State Immunity, ${ }^{107}$ but only superfluously.

Comparable approach can be observed in the case which factual background was similar to Natoniewski cited above. It concerned compensation for the actions of German armed forces during the World War II. The plaintiff claimed compensation from the Federal Republic of Germany for the alleged breach of his personal rights resulting from genetic damages caused by medical experiments carried out on his father as a prisoner of a German concentration camp. The Warsaw Provincial Court in its decision in I C 862/07 ${ }^{108}$ referred only to the judgment of the CJEU in C-292/05 Erini Lechouritou ${ }^{109}$ to emphasize that acts committed by the military belong to acta iure imperii acts of a State. They do not fall under the scope of civil matters and therefore a civil court cannot adjudicate them. The Provincial Court took no notice of other decisions of foreign or international courts that were cited in Natoniewski. Thus the Court missed the opportunity offered by the case to participate in the judicial dialogue.

\section{Conclusions}

The presented research results demonstrate that except for the decisions of the European Court of Human Rights and the Court of Justice of the European Union, the Polish ordinary courts, albeit rarely, refer to the case law of the International Court of Justice, the Human Rights Committee and the courts of other States. The reason why such rare references occur rarely lies in the scope of ordinary courts' jurisdiction, which is focused on private law relations, based primarily on domestic law. The subject matter of the cases only sometimes may require taking into account international or foreign judgments. It happens especially if the case has some link to international law, such as human rights law, State immunity (customary international law) or European Union law.

105 See Supreme Court cases: R 133/26 (2 March 1926); I C 1680/27 (10 February 1928); II C 413/37 (31 August 1937); III PZP 9/90 (26 September 1990); I PKN 562/99 (11 January 2000); I CK 380/02 (13 November 2003).

106 Convention on diplomatic relations (Vienna, 18 April 1961).

107 European Convention on State Immunity (Basel, 16 February 1972).

108 Case I C 862/07 (Warsaw Provincial Court, 3 September 2008).

109 Case C-292/05 Erini Lechouritou and others v Dimosio tis Demokratias tis Germanias (CJEU, 15 February 2007). 
The most common practice of ordinary courts is to quote the decisions without their detailed examination. The purpose of such citation is only to support the courts' own reasoning. However, there were also exceptional rulings of a comparative and critical character as the judgment of the Wroclaw District Court in X P 384/13 concerning the freedom of speech of an employee, the judgment on the obligation to remove a Sikh's turban in certain circumstances as in Mr. S.P. (I CSK 439/13), the order of the Warsaw Provincial Court in XXI Pz 95/14 on State immunity from the enforcement proceedings and the judgments of the Polish Supreme Court in Natoniewski (IV CSK 465/09), the decision of the Warsaw Appellate Court in case concerning clickable links (I ACa 1663/13), the three cases concerning the notion of an entrepreneur's seat for the purposes of the insolvency proceedings (II CSK 406/10, II CSK 541/10 and II CSK 326/10) and the judgment of the Appellate Court in Bialystok on contract of currency option (I ACa 833/12). In the above mentioned judgments the Polish courts not only merely cited the decisions of other jurisdictions, but they analysed them in detail and widely discussed, considering whether an analogous reasoning could be applied with respect to Polish law.

For a judicial dialogue to have its proper discursive character, Polish courts should not only refer to the rulings of international and foreign courts, but their views should be noticed likewise by international or foreign courts. It is worth noticing, that the Supreme Court's decision in Natoniewski contributed to the international dialogue on immunities of State, owing to its English translation published in Polish Yearbook of International Law. It subsequently was discussed by the International Court of Justice in Jurisdictional Immunities of the State (Germany v Italy: Greece Intervening) and by the European Court of Human Rights in Jones and Others $v$ the United Kingdom. One must conclude, therefore, that if Polish judges wish to have their part in a discussion on vital issues of international law, their decisions should be made accessible in foreign languages.

It must be appraised that some of the Polish ordinary courts try, however rarely, to participate in the dialogue with the courts of different jurisdictions. Even though the lack of knowledge of a given foreign language (for example a modern Greek) impedes the judges from becoming acquainted with foreign judgments, they learn about the external jurisdictions with the help of the Ministry of Justice or, more often, legal publications in a specific field. It is obvious that the activity of scholars in the sphere of comparative law becomes thus more important.

One of the examples where the scholarly work had an impact on a reasoning of a court was the decision of the Warsaw Appellate Court in I ACa 410/13, ${ }^{110}$ where basing on the book of J. Rosén ${ }^{111}$ the Court quoted the ruling of the England

110 Case I ACa 410/13 (Warsaw Appellate Court, 28 October 2013).

111 J. Rosén, Intellectual Property at the Crossroads of Trade (Edward Elgar 2012). The Court wrote that it cited the text of Amanda Michaels from the mentioned book. It must be pointed out, however, that whilst Amanda Michaels is a known author in the field of the intellectual property law, she is not one of the authors of the invoked book. 
and Wales High Court in Jean Christian Perfumes Ltd and Anor $v$ Thakrar. ${ }^{112}$ The aim of this citation was to strengthen the opinion presented by the Warsaw Appellate Court in the statement of reasons. Another example is the resolution of the Polish Supreme Court (I KZP 21/06 ${ }^{113}$ ), in which the Court, citing the article of a scholar, ${ }^{114}$ referred to the two decisions of the High Court of Ireland in Fal$\operatorname{lon}^{115}$ and to opinion of the Belgian Cour de Cassation. ${ }^{116}$ The aim of these references was the presentation of different approaches of national courts of other EU member States to the analyzed subject matter (European arrest warrant). Similarly, the above mentioned cases on the application of the CMR Convention ${ }^{117}$ referred to foreign decisions on the basis of their quoting in the articles in the journal European Transport Law.

In the judgment in Natoniewski the Polish Supreme Court got the information about the quoted international and foreign decisions and their content from the opinion of the Ministry of Justice, which was delivered on the basis of the Code of Civil Procedure. ${ }^{118}$ The other sources were the websites of the CJEU or the International Civil Service Commission or Polish Professional software (e.g. LEX). The Court found some information in the legal literature, e.g. the Polish magazine Kwartalnik Prawa Publicznego (Public Law Quarterly).

The judicial dialogue of Polish ordinary courts suffers from several drawbacks. Usually the review of international or foreign decisions is superficial, as it is restricted to a mere reference, therefore it can be classified as a decorative dialogue. Unfortunately, there are also some other factors or improper practices that hamper judicial dialogue. For ordinary courts the most noticeable problem is an adequate quoting of international and foreign decisions that sometimes produce humorous results. The most remarkable example is naming the ECtHR as "the European

112 Jean Christian Perfumes Ltd \& Anor v Thakrar (t/a Brand Distributor or Brand Distributors Ltd) (England and Wales High Court, 27 May 2011). Unfortunately, the Warsaw Appellate Court cites the judgment with the inaccuracies. The England and Wales High Court is named "English High Court", which is incorrect.

113 Case I KZP 21/06 (Supreme Court, 21 July 2006).

114 M. Hudzik, 'Europejski nakaz aresztowania a nieletni sprawcy czynów zabronionych - zagadnienia wybrane' (2006) 8 Europejski Przegląd Sądowy 22. What is interesting, is the fact that the article was published in August 2006, whereas the Court's resolution is of July 2006 and the Court indicated, that the official publication of the article was pending at that time.

115 Minister for Justice Equality and Law Reform v Fallon aka Micheal O Falluin (High Court of Ireland, 9 September 2005), Minister for Justice Equality and Law Reform v Fallon aka Micheal O Falluin (High Court of Ireland, 14 October 2005), The Supreme Court inaccurately wrote the party's name (Falkon instead of Falluin).

116 Case P.05.0065.N (Belgian Cour de Cassation, 25 January 2005).

117 Case I ACa 111/13 (Szczecin Appellate Court, 9 May 2013), Case I ACa 696/03 (Warsaw Appellate Court, 4 February 2003), Case VIII Ga 31/13 (Szczecin Provincial Court, 8 March 2013).

118 Art. 1143(3) of the Code of Civil Procedure reads: "A court ex officio determines and applies proper foreign law. A court may ask the Minister of Justice for the information on the text of this law and for the explanation of foreign judicial practice." 
Court of Human Rights in S." where 'S.' stands for 'Strasbourg' or "the Court of Justice in L." with 'L.' meaning 'Luxembourg.'119 The citation often lacks names of parties, dates of judgments or case numbers. ${ }^{120}$ These inaccuracies are easy to overcome; nevertheless, they may clearly hamper the judicial discourse.

119 "Wprawdzie w orzecznictwie Europejskiego Trybunału Praw Człowieka w S. oraz Sądu Najwyższego, język i forma wypowiedzi prasowych podlegają ochronie, ale jednak w granicach prawa do czci tak jak swoboda wypowiedzi", [in:] Case I ACa 931/14 (Lodz Appellate Court, 30 December 2014). "Orzecznictwo Europejskiego Trybunału w S.", [in:] Case I ACa 617/13 (Bialystok Appellate Court, 20 December 2013).

120 "M.A. N., C. i inni przeciwko Polsce - decyzja ETPC z dnia 14 maja 2013 r., skarga nr [...] (w:) M.A. N., Europejski Trybunał Praw Człowieka. Wybór orzeczeń 2013, LEX/el., 2014", [in:] III AUa 21/14 (Szczecin Appellate Court, 23 September 2014); "orzeczenie z dnia 26 kwietnia 1979 r. w sprawie [...] v. Wielka Brytania (I), skarga [...], LEX nr 80817; orzeczenie z dnia 23 maja 1991 r. w sprawie O. v. Austria, skarga [...], LEX nr 81177; orzeczenie z dnia 8 lipca 1986 r. w sprawie L. v. Austria, skarga [...], LEX nr 81012", [in:] I ACa 662/12 (Lodz Appellate Court, 1 October 2012); "Jak wskazał Europejski Trybunat Praw Człowieka w wyroku z dnia 19 kwietnia 2001 r. (P. przeciwko Grecji, sprawa 28524/95)", [in:] I ACa 966/12 (Warsaw Appellate Court, 31 January 2013); “Pozostaje ona zatem w wyraźnej opozycji do wskazań zawartych w uzasadnieniu w wyroku ETPCz z dnia 10 maja 2011 r. (nr skargi [...])", [in:] II AKa 185/14 (Bialystok Appellate Court, 18 September 2014); "W żadnym przeto wypadku wyrok Europejskiego Trybunału Praw Człowieka z 14 czerwca 2011 r. - sprawa M. G. przeciwko Polsce, skarga nr [...] nie mógł mieć precedensowego charakteru w niniejszej sprawie", [in:] V ACa 535/12 (Katowice Appellate Court, 13 February 2014); "Dla rozstrzygnięcia omawianego zagadnienia istotne znaczenie ma też wyrok Europejskiego Trybunału Praw Człowieka z 2 marca 2010 r., nr 13102, P. K. przeciwko Polsce, w którym podkreślono", [in:] I ACa 40/14 (Warsaw Appellate Court, 26 June 2014); "Na tle tej dyrektywy, Trybunał Sprawiedliwości w sprawie C-388/07 rozpoznał kilka pytań prejudycjalnych w przedmiocie wykładni dyrektywy", [in:] IV IP 300/09 (Wroclaw Provincial Court, 16 July 2010); "Sprawa mieści się więc w pojęciu sprawy cywilnej i handlowej, rozumianej w sposób ugruntowany w orzecznictwie Trybunału Sprawiedliwości (por. np. wyrok ETS z dnia 14 listopada 2002 r., C-271/00 Slg. 2002, I-10489)", [in:] IV CSK 202/13 (Supreme Court, 28 February 2014); "Także Trybunał Sprawiedliwości Unii Europejskiej w wyroku z dnia 19 grudnia 2012 r. wydanym w sprawie prejudycjalnej A. e. A. (C-325/11)", [in:] I ACz 1479/13 (Bialystok Appellate Court, 5 December 2013); "porównaj między innymi wyroki ETS z dnia 11 lipca 2008 r. C-195/08 PPU, Dz. Urz. UE, C-223 z dnia 30 sierpnia 2008 r. i z dnia 22 grudnia 2010 r., C-491/10, PPU, Dz. U. UE, C-2011.63/23 z dnia 26 lutego 2011 r. i z dnia 22 grudnia 2010 r., C-497/10, PPU, Dz. U. UE, C-2011.55.17 z dnia 19 lutego 2011 r.", [in:] I CSK 426/14 (Supreme Court, 17 September 2014). It is worth noticing, that the 'PPUs' used in all of the cases are not the names of the parties to the proceedings, but they are a shortcut for 'preliminary ruling' (pytanie prejudycjalne). "W wyroku ETS z dnia 13 grudnia 2007 r. wydanym w trybie prejudycjalnym rozstrzygnięto bowiem, że...", [in:] I ACz 186/12 (Katowice Appellate Court, 6 March 2012); "tak m.in. wyrok Trybunału Sprawiedliwości z 10 kwietnia 1984 r. w sprawie 14/83 von C., pkt 26; wyrok z 13 listopada 1990 r. w sprawie C-106/89 M., pkt 8; wyrok z 5 października 2004 r. w połączonych sprawach C-397/01 do C-403/01 P. $i$ in., pkt 113 i 115", [in:] I ACa 1166/13 (Warsaw Appellate Court, 11 March 2014). It is worth noticing that "wyrok Trybunału Sprawiedliwości z 10 kwietnia 1984 r. w sprawie 14/83 von C." means the "case 14/83 Von Colson and Kamann v. Land Nordrhein-Westfalen (CJEU, 10 April 1984)", which is a very well-known and recognizable judgment of the CJEU. 


\section{Bibliography}

\section{Case law}

\section{International courts}

\section{CJEU}

14/83 Von Colson and Kamann v Land Nordrhein-Westfalen (10 April 1984)

C-172/91 Volker Sonntag v Hans Waidmann, Elisabeth Waidmann and Stefan Waidmann (21 April 1993)

C-306/05 Sociedad General de Autores y Editores de España (SGAE) v Rafael Hoteles SA (7 February 2006)

C-341/04 Eurofood IFSC Ltd. (2 May 2006)

C-292/05 Erini Lechouritou and others v Dimosio tis Demokratias tis Germanias (15 February 2007)

C-466/12 Nils Svensson, Sten Sjögren, Madelaine Sahlman, Pia Gadd v Retriever Sverige AB (13 February 2014)

\section{ECtHR}

Xv United Kingdom, App. no. 7992/77 (12 July 1978)

Jersild v Denmark, App. no. 15890/89 (23 September 1994)

Nilsen and Johnsen $v$ Norway, App. no. 23118/93 (25 November 1999)

Waite and Kennedy $v$ Germany, App. no. 26083/94 (18 February 1999)

Fuentes Bobo v Spain, App. no. 39293/98 (29 February 2000)

McElhinney v Ireland, App. no. 31253/96 (21 November 2001)

Al-Adsani v the United Kingdom, App. no. 35763/97 (21 November 2001)

Kalogeropoulou and others $v$ Greece and Germany, App. no. 59021/00 (12 December 2002)

Phull v France, App. no. 35753/03 (11 January 2005)

Wojtas-Kaleta v Poland, App. no. 20436/02 (16 July 2009)

Mann Singh v France, App. no. 24479/07 (27 November 2008)

Palomo Sanchez and others $v$ Spain, App. no. 28955/06 (12 September 2011)

Sosinowska v Poland, App. no. 10247/09 (18 October 2011)

Moczulski v Poland, App. no. 49974/08 (19 November 2011)

Jones and Others $v$ the United Kingdom, App. no. 34356/06 and 40528/06 (14 January 2014)

\section{IACtHR}

Compulsory Membership in an Association Prescribed by Law for the Practice of Journalism, Advisory Opinion OC-5/85, Inter-American Court of Human Rights Series A No. 5 (13 November 1985)

\section{ICJ}

Barcelona Traction, Light and Power Company (Belgium v Spain) (24 July 1964)

Case concerning the arrest warrant of 11 April 2000 (Democratic Republic of the Congo v Belgium

(14 February 2002)

Jurisdictional immunities of the State (Germany v Italy: Greece intervening) (3 February 2012) 


\section{Other international bodies}

\section{Human Rights Committee}

Mann Singh v France, App. no. 1928/2010 (19 July 2013)

\section{Polish courts}

\section{Supreme Court}

\section{Judgments}

R 133/26 (2 March 1926)

I C 1680/27 (10 February 1928)

C II 413/37 (31 August 1937)

II CKN 321/99 (18 August 1999)

I CK 380/02 (13 November 2003)

V CSK 295/07 (12 December 2007)

III CSK 293/07 (13 March 2008)

IV CSK 465/09 (29 October 2010)

III CZP 16/10 (30 November 2010)

II CSK 326/10 (16 February 2011)

II CSK 406/10 (16 February 2011)

II CSK 541/10 (16 February 2011)

III CZP 25/11 (18 October 2011)

II KK 296/11 (13 June 2012)

IV CSK 309/12 (8 February 2013)

II PK 207/12 (27 February 2013)

IV CSK 202/13 (28 February 2014)

I CSK 439/13(17 September 2014)

I CSK 426/14 (17 September 2014)

\section{Orders}

I PKN 562/99 (11 January 2000)

III CSK 293/07 (13 March 2008)

III KK 152/10 (30 November 2010)

III KK 327/12 (5 April 2013)

IV CSK 202/13 (28 February 2014)

II KK 265/13 (19 March 2014)

I PZ 19/14 (28 October 2014)

\section{Resolutions}

I KZP 21/06 (21 July 2006)

III CZP 113/13 (7 February2014)

I PZ 19/14 (28 October 2014) 
Resolutions of Seven Judges

III PZP 9/90 (26 September 1990)

\section{Bialystok Appellate Court}

\section{Judgments}

I ACa 833/12 (21 January 2013)

I ACa 617/13 (20 December 2013)

II AKa 185/14 (18 September 2014)

\section{Orders}

I ACz 1479/13 (5 December 2013)

\section{Katowice Appellate Court}

\section{Judgments}

V ACa 535/12 (13 February 2014)

\section{Orders}

I ACz 186/12 (6 March 2012)

\section{Lodz Appellate Court}

\section{Judgments}

I ACa 662/12 (1 October 2012)

I ACa 931/14 (30 December 2014)

\section{Lublin Appellate Court}

\section{Judgments}

II AKa 91/11 (6 June 2011)

\section{Szczecin Appellate Court}

\section{Judgments}

I ACa 758/12 (20 December 2012)

I ACa 111/13 (9 May 2013)

III AUa 21/14 (23 September 2014) 
Warsaw Appellate Court

Judgments

I ACa 696/03 (4 February 2003)

I ACa 201/12 (20 September 2012)

I ACa 966/12 (31 January 2013)

I ACa 410/13 (28 October 2013)

I ACa 1166/13 (11 March 2014)

I ACa 1663/13 (7 May 2014)

I ACa 40/14 (26 June 2014)

\section{Wroclaw Appellate Court}

\section{Orders}

II AKz 340/10 (17 June 2010)

II AKz 542/10 (26 October 2010)

\section{Szczecin Provincial Court}

\section{Judgments}

VIII Ga 31/13 (8 March 2013)

\section{Warsaw Provincial Court}

\section{Orders}

I C 862/07 (3 September 2008)

XXI Pz 95/14 (26 June 2014)

\section{Wroclaw Provincial Court}

\section{Judgments}

IV IP 300/09 (16 July 2010)

\section{Wroclaw District Court}

\section{Judgments}

X P 384/13 (7 June 2013)

\section{Other States' courts}




\section{Belgium}

\section{Cour de Cassation}

P.05.0065.N (25 January 2005)

\section{France}

\section{Cour de Cassation}

82-12462 Islamic Republic of Iran v Société Eurodif and others (14 March 1984)

00-87215 Qaddafi (13 March 2001)

\section{Germany}

\section{Constitutional Court}

2 BvM 1/76 (13 December 1977)

\section{Federal Tribunal}

XI ZR 33/10 (22 March 2011)

\section{Greece}

\section{Special Supreme Court}

111/2000 Perfectory Voiotia v Germany (Distomo) (4 May 2000)

6/2002 Margellos v Germany (17 September 2002)

\section{Italy}

\section{Corte di Cassazione}

5044/2004 Ferrini v Germany (11 March 2004)

1072/08 Civitella (21 October 2008)

\section{United Kingdom}

\section{England and Wales High Court}

Jean Christian Perfumes Ltd \& Anor v Thakrar (t/a Brand Distributor or Brand Distributors Ltd.)

(27 May 2011)

\section{High Court of Ireland}

Minister for Justice Equality and Law Reform v Fallon aka Micheal O Falluin (9 September 2005)

Minister for Justice Equality and Law Reform v Fallon aka Micheal O Falluin (14 October 2005)

\section{High Court of Justice in London}

Enron Directo SA (4 July 2002 and 10 December 2002) 


\section{House of Lords}

Alcom Ltd. $v$ Republic of Colombia (12 April 1984)

Commissioner of Police for the Metropolis and Others, Ex Parte Pinochet (24 March 1999)

Jones $v$ Saudi Arabia (14 June 2006)

\section{United States of America}

\section{Supreme Court}

Republic of Austria v Maria Altmann (7 June 2004)

\section{Court of Appeals, 9 Circuit}

Liu $v$ Republic of China (29 December 1989)

\section{Court of Appeals, 2 Circuit}

Bruce Smith v Socialist People's Libyan Arab Jamahiriya (26 November 1996)

\section{Circuit Court of Appeals}

Guy von Dardel v the USSR (15 October 1985)

Hugo Princz v Federal Republic of Germany (14 April 2003)

\section{District Court (New York)}

Hirsch $v$ State of Israel and State of Germany (8 April 1997)

\section{References}

\section{Books and articles}

Hudzik M., 'Europejski nakaz aresztowania a nieletni sprawcy czynów zabronionych - zagadnienia wybrane' (2006) 8 Europejski Przegląd Sądowy 22

Mik C., 'Jus cogens in contemporary international law' (2013) Polish Yearbook of International Law XXXIII 27

Rosén J., Intellectual Property at the Crossroads of Trade (Edward Elgar 2012)

\section{Webistes}

Biuletyn Informacji Publicznej, 'Lista sądów powszechnych', <https://bip.ms.gov.pl/pl/rejestry-i-ewidencje/lista-sadow-powszechnych/> (access: 21 November 2015)

Biuletyn Informacji Publicznej, 'Orzecznictwo Europejskiego Trybunału Praw Człowieka', <https:// bip.ms.gov.pl/pl/prawa-czlowieka/europejski-trybunal-praw-czlowieka/orzecznictwo-europejskiego-trybunalu-praw-czlowieka/> (access: 2 October 2015)

Biuletyn Informacji Publicznej, 'Nowe tłumaczenia wyroków Europejskiego Trybunału Praw Człowieka na język polski’, <https://www.msz.gov.pl/pl/polityka_zagraniczna/europejski_trybunal_ praw_czlowieka/aktualnosci/nowe_tlumaczenia_wyrokow_europejskiego_trybunalu_praw_ czlowieka_na_jezyk_polski> (access: 2 October 2015) 